\title{
Statistical analysis plans (SAPS) for academic clinical trials at the edinburgh clinical trials unit: what should they contain?
}

\author{
Aryelly Rodriguez $2^{*}$, Steff Lewis ${ }^{1,2}$, Gordon Murray ${ }^{1,2}$, Ashma Krishan², Isabella Butcher ${ }^{1}$, Christopher Weir ${ }^{1,3}$ \\ From 2nd Clinical Trials Methodology Conference: Methodology Matters \\ Edinburgh, UK. 18-19 November 2013
}

Once a study protocol is final, the creation of the Statistical Analysis Plan (SAP) can commence. Accordingly to ICH E9 a SAP "contains a more technical and detailed elaboration of the principal features of the analysis described in the protocol" but the level of detail is not specified. This topic is currently being discussed between UK-CRC registered Trials Units, and there is as yet no agreement on the amount of detail that should be covered in the SAP. Within the Edinburgh Clinical Trials Unit (ECTU), we created a consensus document outlining what we thought the essential aspects of a SAP should be.

Briefly, we set out the essential aspects of a SAP as follows. It should be written by someone who has not seen unblinded data from the trial, and should describe analyses unambiguously and in sufficient detail for another statistician to be able to repeat them. It should include a brief description of the trial design, and the statistical methods section from the protocol. Analysis populations, e.g. ITT, per protocol, should be defined in an unambiguous fashion. The SAP should state overall level of significance, and any other relevant information that will be used in the majority of analyses (e.g. treatment of missing data, adjustment for covariates, adjustment for multiplicity, adjustment of p-value due to interim analyses). A list of analyses should describe each precise outcome, the analysis method to be used, any sensitivity analyses, any deviations from the methods listed in 'Overall Statistical Principles', and any subgroup analyses.

\section{Authors' details}

${ }^{1}$ Centre for Population Health Sciences-University of Edinburgh, Edinburgh, UK. ${ }^{2}$ ECTU-University of Edinburgh, Edinburgh, UK. ${ }^{3} \mathrm{HSRU}$, Edinburgh, UK.

${ }^{2}$ ECTU-University of Edinburgh, Edinburgh, UK

Full list of author information is available at the end of the article
Published: 29 November 2013

doi:10.1186/1745-6215-14-S1-0102

Cite this article as: Rodriguez et al:: Statistical analysis plans (SAPS) for academic clinical trials at the edinburgh clinical trials unit: what should they contain? Trials 2013 14(Suppl 1):0102.
Submit your next manuscript to BioMed Central and take full advantage of:

- Convenient online submission

- Thorough peer review

- No space constraints or color figure charges

- Immediate publication on acceptance

- Inclusion in PubMed, CAS, Scopus and Google Scholar

- Research which is freely available for redistribution
() Biomed Central
C Biomed Central

(C) 2013 Rodriguez et al; licensee BioMed Central Ltd. This is an Open Access article distributed under the terms of the Creative Commons Attribution License (http://creativecommons.org/licenses/by/2.0), which permits unrestricted use, distribution, and reproduction in any medium, provided the original work is properly cited. 